DOI https://doi.org/10.30525/978-9934-26-005-6-10

\title{
ГАРМОНІЗАЦІЯ ЯК НОВІТНІЙ ПІДХІД ДО ДЕРЖАВНОГО РЕГУЛЮВАННЯ РОЗВИТКУ МАЛОСУБ'ЄКТНИХ ГАЛУЗЕЙ НАЦІОНАЛЬНОЇ ЕКОНОМІКИ (НА ПРИКЛАДІ АВТОМОБІЛЬНОЇ ПРОМИСЛОВОСТІ УКРАЇНИ)
}

\author{
Шевченко І. Ю. \\ доктор економічних наук, дочент, \\ завідувач кафедри економіки і підприємництва \\ Харківського начіонального \\ автомобільно-дорожнього університету \\ м. Харків, Україна
}

У багатьох країнах світу потужним драйвером соціальноекономічного розвитку виступає автомобільна промисловість інноваційно активна підгалузі машинобудування та роботодавець, який забезпечує роботою не лише працівників автомобілебудівних підприємств, а й працівників підприємств суміжних галузей у співвідношенні 1:6. Розвиток автомобільної індустрії в країні має не лише позитивні внутрішні соціальноекономічні ефекти, а й сприяє входженню держави до світового соціально-економічного простору. Тому уряди багатьох країн докладали значних зусиль задля становлення та розвитку національних автовиробників.

Історія світової автомобільної індустрії містить яскраві приклади становлення автомобільної промисловості в Японії, Південній Кореї, Китаї, Індії, країнах Свропейського Союзу, яке зазвичай відбувалося за ініціативи урядів країн і повсякчасного державного протекціонізму. Лише в США становлення автомобільної індустрії початково забезпечувалося ініціативою інженерів-підприємців, але в часи економічної кризи автовиробники були змушені звернутися до держави за підтримкою, що дало старт продуктивному державноприватному партнерству [1].

48 
В Україні автомобільна промисловість тривалий час розвивалася за інерційним сценарієм як частина радянського автопрому. Закритість кордонів призвела до дефіциту трансферу інновацій i, тим самим, спричинила технічну відсталість автомобілів вітчизняного виробництва. Додатково до застарілої техніко-технологічної бази, слабкими сторонами підприємств українського автопрому виявилися низька клієнтоорієнтованість і відсутність достатнього досвіду роботи в умовах ринкової економіки та конкурентної боротьби. Як наслідок, вітчизняні автовиробники фактично не мають змоги конкурувати зі світовими автоконцернами [2].

Така ситуація не могла не позначитися негативним чином на автопромі України та призвела до зменшення кількості автомобілебудівних підприємств. На сьогодні автомобілебудівна підгалузь машинобудування України нараховує всього лише 8 акціонерних товариств - «Запорізький автомобілебудівний завод», «Богдан Моторс», «Сврокар», «АвтоКрАЗ», «Бориспільський автозавод», «Часівоярські автобуси», «Чернігівський автозавод», «Черкаський автобус», що робить вітчизняну автомобільну промисловість малосуб'єктною підгалуззю національної економіки.

3 одного боку, малосуб'єктність автомобільної промисловості України можна розглядати як іiі слабку сторону, ознаку спаду та навіть подекуди регресу внаслідок неможливості повноцінно конкурувати зі світовими автоконцернами навіть на національному автомобільному ринку. 3 іншого боку, невелика кількість національних автовиробників в Україні створює умови для використання гармонізації як новітнього підходу до державного регулювання розвитку автомобільної індустрії.

Гармонізаційний підхід до державного регулювання розвитку галузей національної економіки спирається на фундамент державно-приватного партнерства та може бути реалізований лише за умови малосуб'єктності галузі/підгалузі, адже передбачає взаємне узгодження (гармонізацію) концептів державної стратегії/програми розвитку галузі/підгалузі та конкурентних стратегій суб'єктів виду економічної діяльності. 
Методичну основу реалізації гармонізаційного підходу до державного регулювання розвитку автомобільної промисловості складають:

- тесеракт конкурентоспроможності як генератор концепції сталого розвитку автомобільної індустрії. Грані внутрішнього куба тесеракту як елементи конкурентоспроможності підприємств автомобілебудівної підгалузі представлено у вигляді поєднання елементів конкурентоспроможності автомобілебудівної продукції («ціна», «якість», «асортимент» $\mathrm{i}$ «сервісне обслуговування») та елементів конкурентного потенціалу автовиробників («виробничий потенціал», «кадровий потенціал», «управлінський потенціал», «інноваційний потенціал», «фінансовий потенціал», «інвестиційний потенціал», «ринковий потенціал» $\mathrm{i}$ «стратегічний потенціал»). Вершини внутрішнього куба тесеракту як точки перетину його граней $\epsilon$ точками виходу (початку) прямих, які з'єднують внутрішній i зовнішній куби тесеракту й уособлюють інструменти забезпечення конкурентоспроможності автомобілебудівних підприємств. Точки закінчення зазначених прямих служать вершинами зовнішнього куба тесеракту конкурентоспроможності та формують концепти (базові елементи концепції сталого розвитку автомобільної індустрії) у вигляді сторін зовнішнього куба;

- уніфікована модель заходів державного протекціонізму розвитку автомобільної промисловості. Модель сформовано у вигляді матриці на підставі уніфікації передового зарубіжного досвіду державного протекціонізму розвитку автомобільної промисловості в залежності від етапу життєвого циклу автомобільної індустрії в системі національної економіки (за критеріями внеску до ВВП i зайнятості населення) та конкурентного статусу національних автовиробників на внутрішньому автомобільному ринку [1];

- матриця конкурентних стратегій автовиробників, якою враховуються їх етапи життєвого циклу та рівень конкурентоспроможності (задля подальшою гармонізації 3 уніфікованою моделлю заходів державного протекціонізму розвитку автомобільної промисловості) з урахуванням дуальної типологізації регіональних ринків продажу автомобілів [3; 4]; 
- алгоритм гармонізації елементів моделі формування державної стратегії/програми розвитку автомобільної промисловості, яким передбачено поетапне усунення бінарних протиріч між згенерованими концептами державної стратегіі/ програми сталого розвитку автомобільної індустрії, комплексом заходів державного протекціонізму розвитку автомобільної промисловості та стратегічними наборами автомобілебудівних підприємств з урахуванням типів регіоналізації національного автомобільного ринку [5].

\section{Література:}

1. Dmytriiev, I., Shevchenko, I., Kudryavtsev, V., Lushnikova, O. \& Zhytnik, T. (2019), The world experience and a unified model for government regulation of development of the automotive industry. Public Policy and Administration. Vol. 18, No 3, P. 46-58. DOI: 10.5755/j01.ppaa.18.3.24720

2. Dmitriiev, I. \& Shevchenko, I. (2017), Problems and prospects of development of the automotive industry in Ukraine. Scientific Journal of Polonia University. Częstochowa: Akademia Polonijna w Częstochowie, No 20(1), P. 11-23. DOI: 10.23856/2001

3. Dmytriiev, I., Shevchenko, I., Dmytriieva, O., Dzhereliuk, I. \& Serohina T. (2020), Methodological and applied aspects of forming the competitive strategy of an enterprise based on typologization of regional markets (using the example of the automotive industry). Financial and credit activity: problems of theory and practice. Vol 2, No 33. P. 107-116. DOI: $10.18371 /$ fcaptp.v2i33.206563

4. Shevchenko, I. (2018), Methodical principles of typology of passenger cars regional markets. Management. Issue 1(27). P. 91-99. DOI: $10.30857 / 2415-3206.2018 .1 .8$

5. Шевченко, І. Ю. Алгоритм гармонізації елементів моделі формування державної стратегії розвитку автомобілебудування. Проблеми $і$ перспективи розвитку підприємництва: Збірник наукових праць Харківського національного автомобільнодорожнього університету. 2019. № 1(22). С. 180-199. DOI: $10.30977 / \mathrm{ppb} .2226-8820.2019 .22 .0 .180$ 